\title{
Poverty, dirt, infections and non-atopic wheezing in children from a Brazilian urban center
}

\author{
Mauricio L Barreto ${ }^{1 *}$, Sergio S Cunha ${ }^{2}$, Rosemeire Fiaccone ${ }^{3}$, Renata Esquivel ${ }^{1}$, Leila D Amorim³ , Sheila Alvim', \\ Matildes Prado ${ }^{1}$, Alvaro A Cruz ${ }^{4}$, Philip J Cooper ${ }^{5}$, Darci N Santos ${ }^{1}$, Agostino Strina ${ }^{1}$, Neuza Alcantara-Neves ${ }^{6}$, \\ Laura C Rodrigues ${ }^{7}$
}

\begin{abstract}
Background: The causation of asthma is poorly understood. Risk factors for atopic and non-atopic asthma may be different. This study aimed to analyze the associations between markers of poverty, dirt and infections and wheezing in atopic and non-atopic children.

Methods: 1445 children were recruited from a population-based cohort in Salvador, Brazil. Wheezing was assessed using the ISAAC questionnaire and atopy defined as allergen-specific lgE $\geq 0.70 \mathrm{kU} / \mathrm{L}$. Relevant social factors, environmental exposures and serological markers for childhood infections were investigated as risk factors using multivariate multinomial logistic regression.

Results: Common risk factors for wheezing in atopic and non-atopic children, respectively, were parental asthma and respiratory infection in early childhood. No other factor was associated with wheezing in atopic children. Factors associated with wheezing in non-atopics were low maternal educational level (OR 1.49, 95\% Cl 0.98-2.38), low frequency of room cleaning (OR 2.49, 95\% Cl 1.27-4.90), presence of rodents in the house (OR 1.48, 95\% Cl 1.06-2.09), and day care attendance (OR 1.52, 95\% Cl 1.01-2.29).

Conclusions: Non-atopic wheezing was associated with risk factors indicative of poverty, dirt and infections. Further research is required to more precisely define the mediating exposures and the mechanisms by which they may cause non-atopic wheeze.
\end{abstract}

\section{Background}

An estimated 300 million people have asthma worldwide; the prevalence has increased over the past 40 years or so among children in industrialized countries [1] and has increased more recently in some developing countries [2]. Asthma is frequently described as an allergic disease, but this does not reflect the complexity of current evidence: although allergic children are more likely to develop asthma, a large proportion of children with asthma do not appear to be allergic. The International Study of Asthma and Allergic diseases in Childhood (ISAAC), an international survey of the prevalence of asthma and other allergic diseases that used a standardized questionnaire and measures of atopy found that the population fraction of asthma attributable to

\footnotetext{
* Correspondence: mauricio@ufba.br

${ }^{1}$ Instituto de Saúde Coletiva, Universidade Federal da Bahia, Salvador, Brazil Full list of author information is available at the end of the article
}

atopy differed greatly between countries by economic development: $40.7 \%$ in study centers from 'affluent' countries and $20.3 \%$ in centers from 'non-affluent' countries [3]. The prevalence of reported asthma symptoms is as high in urban centers in Latin America as in the UK and the USA [4], but the proportion attributable to atopy is low $[5,6]$.

The causation of asthma is poorly understood. Risk factors reported for asthma as a whole, and for atopic and non-atopic asthma vary between studies and it is likely therefore that the causal mechanisms that underlie these two asthma phenotypes may differ also. Given the increase in the prevalence of asthma among atopic children, understanding why some children become atopic may also contribute to identification of new prevention measures. Very few studies have investigated separately risk factors associated with atopic and non-atopic asthma in the same population [6-13]. A problem in

C Biomed Central

C 2010 Barreto et al; licensee BioMed Central Ltd. This is an Open Access article distributed under the terms of the Creative Commons Attribution License (http://creativecommons.org/licenses/by/2.0), which permits unrestricted use, distribution, and reproduction in any medium, provided the original work is properly cited. 
interpreting these studies is that they are not consistent in the choice of comparison groups: approaches used include, among others, comparing both types of asthma with non asthmatic children (irrespective of their atopic status), comparing both groups to non atopic non asthmatic children, or comparing atopic asthmatics with atopic children without asthma, and non atopic asthmatics with non atopic children without asthma. A table summarizing the findings of these studies and the methodological approach they adopted is presented in Table 1. Different choices of comparison groups of course implicitly reflect different study questions and lead to different results. To contribute to the improvement in the design and analysis of population-based studies in this field and to allow studies to be compared more easily, we propose a solution to this conundrum: to be explicit about which question is answered by choosing different comparison groups, and to use the comparison group that is more informative. We propose a framework which makes explicit the assumptions used in the analysis and therefore a better interpretation of findings, enabling the understanding of the complex relationships between atopy, atopic asthma and non atopic asthma (Figure 1). According to this framework, the most informative approach is to investigate separately risk factors for asthma among non-atopic children and those for asthma among atopic children, and risk factors for being atopic in the overall population. We have applied this strategy in the present study to investigate the relationships between risk factors associated with poverty, dirt and infections and wheezing in atopic and non-atopic children and separately for atopy in urban Brazil.

\section{Methods}

\section{Study area, population and design}

This study is part of a cohort study of asthma and allergies conducted in Salvador, a large city in Northeast Brazil with a high prevalence of wheezing reported in the ISAAC surveys [14]. Methods have been described in details elsewhere [15]. Briefly, the study population consists of a cohort of 1,445 children previously studied to evaluate the impact of a sanitation program and enrolled when they were 0-3 years old in the period 1996 to 2003 [16-18]. This first study was originally designed to enroll three separate cohorts of children aged 0-3 years recruited in 1997, 2001 and 2003, respectively, from 24 small sentinel-areas selected to represent the population without sanitation in Salvador [19]. For each cohort, children were randomly selected among those living in the areas. Sampling and data collection procedures and instruments were the same in the 3 surveys and follow-up, thus making the study populations comparable. Within each selected area, a survey was conducted at baseline and each cohort was then followed-up.regularly for a period of one year from recruitment. During follow-up, children were visited every 2 weeks and data on occurrence of diarrhoea, cough, shortness of breath and fever as reported by the guardian were collected. To take advantage of these three cohorts (since detailed information for them had been collected on early life factors proposed as potential risk factors for asthma and other allergic diseases), the children who were aged 4-11 years and had complete follow-up information were selected for the present study.

The present analysis used outcomes (wheezing and atopy) and exposures measured in 2005 when children were aged 4 to 11 years (demographic and socioeconomic factors, environmental factors, maternal and family factors) and other exposures measured earlier during the first year of follow-up (days of illness with respiratory infections and diarrhea in the first years of life).

\section{Data Collection}

Information was collected, either in the earlier cohort or in 2005, on i) demographic and socioeconomic factors: age, sex, monthly income, maternal schooling, number of electric appliances; ii) environmental factors: sanitation and water supply, electricity, presence of household pets, presence of pets and animals outside household, contact with animals in farms, housing (type of construction), cooking materials; iii) maternal and family factors: maternal smoking during pregnancy and in the first year of life, presence of other household smokers, maternal allergic diseases, duration of breast-feeding, day care attendance, presence of other siblings, birth order, BCG scar and anti-helmintic treatment; iv) exercise/sedentarism: daily hours watching television and frequency of vigorous exercise; v) nutritional factors: Body Mass Index; v) infections: reported incidence of respiratory infection and diarrhea during the first year of follow up. We decided to restrict our analysis to those with at least 90 days of follow-up and classified as low frequency a proportion of days with respiratory illness (ARI) and diarrhea between 1 to 7 days of the follow-up. Day with diarrhea was defined as the report of 3 or more liquid or semi-liquid motions, and day with respiratory illness (ARI) was defined by the simultaneous report of cough, fever and shortness-of-breath in a 24 hours period.

The ISAAC questionnaire, translated into Brazilian Portuguese [20], was applied to parents during household visits. Presence of wheeze was defined by the question, "Have you had wheezing or whistling in the chest in the past 12 months?" All 1,445 children had blood collected for serology to Toxoplasma gondii, Helicobacter pylori, Herpes simplex virus (HSV), Varicella zoster 
Table 1 Summary of the findings of previous studies that analyse in the same population risk factors for atopic or non atopic asthma/wheezing in children

\begin{tabular}{|c|c|c|c|c|c|c|}
\hline \multirow{3}{*}{$\begin{array}{l}\text { Author, outcome, age group } \\
\text { and study sample }\end{array}$} & \multirow{3}{*}{$\begin{array}{c}\text { Studied } \\
\text { Variables }\end{array}$} & \multicolumn{3}{|c|}{ Atopic asthma/wheezing } & \multicolumn{2}{|c|}{ Non atopic asthma/wheezing } \\
\hline & & $\begin{array}{l}\text { Atopic } \\
\text { asthma vs } \\
\text { atopic non- } \\
\text { asthma }\end{array}$ & $\begin{array}{l}\text { Atopic asthma vs } \\
\text { non-asthma } \\
\text { irrespective of } \\
\text { atopy }\end{array}$ & $\begin{array}{l}\text { Atopic } \\
\text { asthma vs } \\
\text { non-atopic } \\
\text { non-asthma }\end{array}$ & $\begin{array}{l}\text { Non-atopic } \\
\text { asthma vs non- } \\
\text { atopic non- } \\
\text { asthma }\end{array}$ & $\begin{array}{l}\text { Non-atopic } \\
\text { asthma" vs non- } \\
\text { asthma irrespective } \\
\text { of atopy }\end{array}$ \\
\hline & & OR $(95 \% \mathrm{Cl})$ & $\begin{array}{l}\text { OR }(95 \% \mathrm{Cl}) \text { or } \\
\text { mean }(\mathrm{sd}) \text { when } \\
\text { indicated }\end{array}$ & OR $(95 \% \mathrm{Cl})$ & OR $(95 \% \mathrm{Cl})$ & $\begin{array}{l}\text { OR }(95 \% \mathrm{Cl}) \text { or } \\
\text { mean }(\mathrm{sd}) \text { when } \\
\text { indicated }\end{array}$ \\
\hline Rönmark et al, 1999 (7) & Male gender & & & & & $1.62(1.03-2.54)$ \\
\hline \multirow{5}{*}{$\begin{array}{l}\text { "ever asthma" in 7-8 year olds } \\
3,141 \text { participants (2,149 skin } \\
\text { tested) }\end{array}$} & $\begin{array}{l}\text { Family history of } \\
\text { asthma }\end{array}$ & & $2.95(1.81-4.81)$ & & & $3.63(2.33-5.66)$ \\
\hline & $\begin{array}{l}\text { Dampness at } \\
\text { home }\end{array}$ & & & & & $1.78(1.10-2.89)$ \\
\hline & Mother smoker & & & & & $1.67(1.04-2.68)$ \\
\hline & $\begin{array}{l}\text { Breast-feeding }<3 \\
\text { months }\end{array}$ & & & & & $1.80(1.11-2.92)$ \\
\hline & Pets at home & & $0.60(0.36-0.98)$ & & & \\
\hline \multirow[t]{2}{*}{$\begin{array}{l}\text { Braun-Fahrländer et al, } 2002 \text { (20) } \\
\text { asthma in 6-13 year olds }\end{array}$} & Endotoxin load & $\begin{array}{l}0.52 \\
(0.25-1.07)^{c}\end{array}$ & & & $1.00(0.46-2.21)^{\mathrm{e}}$ & \\
\hline & $\begin{array}{l}\text { (units } / \mathrm{m}^{2} \text { of } \\
\text { mattress surface) }\end{array}$ & $\begin{array}{l}0.64 \\
(0.33-1.25)^{d}\end{array}$ & & & $1.82(1.04-3.18)^{f}$ & \\
\hline \multirow[t]{5}{*}{812 participants } & $\begin{array}{l}\text { Prevalence of } \\
\text { outcome } \\
\text { according to } \\
\text { farming status }\end{array}$ & & & & & \\
\hline & Farming & $3.1(1.2-5.0)^{9}$ & & & $1.6(0.2-2.9)^{i}$ & \\
\hline & & $4.7(2.4-7.0)^{h}$ & & & $1.6(0.2-2.9)^{\prime}$ & \\
\hline & Non farming & $5.9(3.8-8.0)^{9}$ & & & $2.6(1.2-5.0)^{i}$ & \\
\hline & & $5.9(3.8-8.0)^{\mathrm{h}}$ & & & $6.1(4.0-8.2)^{\prime}$ & \\
\hline Priftanji et al, 2002 (8) & $\begin{array}{l}\text { Mother had } \\
\text { asthma }\end{array}$ & & $2.45(1.06-5.66)$ & & & \\
\hline $\begin{array}{l}\text { asthmatic symptoms in 20-44 } \\
\text { year olds }\end{array}$ & Mother smoked & & & & & $2.66(1.35-5.26)$ \\
\hline 717 participants & $\begin{array}{l}\text { Subject ever } \\
\text { smoked }\end{array}$ & & & & & $1.98(1.17-3.35)$ \\
\hline \multirow{4}{*}{$\begin{array}{l}\text { García-Marcos et al, } 2005 \text { (9) } \\
\text { current wheezing in 9-12 year } \\
\text { olds } 2,720 \text { participants }\end{array}$} & Male gender & $\begin{array}{l}1.53 \\
(1.09-2.14)\end{array}$ & & & & \\
\hline & $\begin{array}{l}\text { Paternal or } \\
\text { maternal asthma }\end{array}$ & $\begin{array}{l}2.16 \\
(1.44-3.22)\end{array}$ & & & $1.74(1.17-2.58)$ & \\
\hline & $\begin{array}{l}\text { Mother smoker } \\
\left(1^{\text {st }} \text { year }\right)\end{array}$ & & & & $2.66(1.13-6.25)$ & \\
\hline & $\begin{array}{l}\text { Mould stains } \\
\text { currently }\end{array}$ & & & & & \\
\hline $\begin{array}{l}\text { Kelley et al, } 2005 \text { (10) } \\
\text { asthma in 6-16 year olds }\end{array}$ & $\begin{array}{l}\text { Mean PIR } \\
\text { (Poverty/Income }^{\text {ratio })^{m}}\end{array}$ & & 2.0 vs $2.2(P<0.5)$ & & & \\
\hline \multirow[t]{2}{*}{ 5,244 participants } & $\begin{array}{l}\text { Mean education } \\
\text { level of adult } \\
\text { respondent } \\
\text { (years) }\end{array}$ & & $\begin{array}{l}12.4 \text { vs } 12.0 \\
(P<0.5)\end{array}$ & & & 12.2 vs $12.0(P<0.5)$ \\
\hline & $\begin{array}{l}\text { Mean BMI } \\
\text { percentile }\end{array}$ & & & & & 68.5 vs $57.7(P<0.5)$ \\
\hline $\begin{array}{l}\text { Janson et al, } 2007 \text { (11) } \\
\text { asthma, 13-14 year olds }\end{array}$ & $\begin{array}{l}\text { BMI (per } 5 \text { units } \\
\text { increase) }\end{array}$ & & $1.62(1.06-2.48)$ & & & $1.55(1.02-2.36)$ \\
\hline 901 participants & Parental asthma & & $2.16(1.12-4.18)$ & & & $2.35(1.23-4.52)$ \\
\hline
\end{tabular}




\begin{tabular}{|c|c|c|c|c|}
\hline & $\begin{array}{l}\text { Early life } \\
\text { infections }\end{array}$ & & & \\
\hline & $\begin{array}{l}\text { Otitis } \\
(\geq 5 / \text { year })\end{array}$ & & & $1.99(1.02-3.88)$ \\
\hline & Croup & & & $2.80(1.44-5.43)$ \\
\hline & $\begin{array}{l}\text { Cat or dog as } \\
\text { infant }\end{array}$ & & & $2.17(1.16-4.04)$ \\
\hline & $\begin{array}{l}\text { Window pane } \\
\text { condensation }\end{array}$ & & & $2.45(1.11-5.40)$ \\
\hline & Dirty school & & & $2.50(1.28-4.89)$ \\
\hline $\begin{array}{l}\text { De Meer et al, } 2009 \text { (12) recent } \\
\text { wheeze in } 8-13 \text { year olds 1,547 } \\
\text { participants }\end{array}$ & $\begin{array}{l}\text { High parental } \\
\text { education }\end{array}$ & $0.89(0.60-1.31)$ & $0.65(0.43-0.99)$ & \\
\hline \multirow{6}{*}{$\begin{array}{l}\text { Kurukulaaratchy et al, } 2010(13) \\
\text { wheeze at } 10 \text { years of age 1,373 } \\
\text { participants (1,036 skin tested) }\end{array}$} & Maternal asthma & & $4.08(1.85-9.00)$ & \\
\hline & $\begin{array}{l}\text { Recurrent chest } \\
\text { infection at } 2 \\
\text { years }\end{array}$ & & $3.99(1.78-8.92)$ & \\
\hline & Sibling asthma & $2.10(1.04-4.23)$ & & \\
\hline & Eczema at 1 year & $2.80(1.01-7.80)$ & & \\
\hline & Rhinitis at 4 years & $4.74(1.61-13.47)$ & & \\
\hline & Male gender & $2.73(1.36-5.48)$ & & \\
\hline \multirow{6}{*}{$\begin{array}{l}\text { Moncayo et al, }(6) \\
\text { recent wheeze in } 6-16 \text { year olds } \\
3,960 \text { participants } \\
(3,821 \text { skin tested) }\end{array}$} & Male gender & $2.73(1.44-5.16)$ & & \\
\hline & $\begin{array}{l}\text { Heavy T. trichiura } \\
\text { infection }\end{array}$ & $0.24(0.09-0.63)$ & & \\
\hline & $\begin{array}{l}\text { Watching TV > } 3 \\
\text { hrs/day }\end{array}$ & & $1.51(1.06-2.16)$ & \\
\hline & $\begin{array}{l}\text { Maternal allergic } \\
\text { diseases }\end{array}$ & & $3.24(2.42-4.32)$ & \\
\hline & Birth order $\geq 4$ & & $0.71(0.57-0.88)$ & \\
\hline & Age $\geq 13$ years & & $0.39(0.25-0.62)$ & \\
\hline
\end{tabular}

a OR $(95 \% \mathrm{Cl})$ for the occurrence of atopic asthma.

b $\mathrm{OR}(95 \% \mathrm{Cl})$ for the occurrence of non-atopic asthma.

c OR $(95 \% \mathrm{Cl})$ for the occurrence of atopic asthma with increase of endotoxine load from the lowest quartile to the highest quartile (children non farming households).

${ }^{d}$ OR $(95 \% \mathrm{Cl})$ for the occurrence of atopic wheeze with increase of endotoxine load from the lowest quartile to the highest quartile (children non farming households).

e $\mathrm{OR}(95 \% \mathrm{Cl})$ for the occurrence of non-atopic asthma with increase of endotoxine load from the lowest quartile to the highest quartile (children non farming households).

${ }^{f} \mathrm{OR}(95 \% \mathrm{Cl})$ for the occurrence of non-atopic wheeze with increase of endotoxine load from the lowest quartile to the highest quartile (children non farming households).

$\mathrm{g}$ atopic asthma.

$\mathrm{h}$ atopic wheeze.

i non-atopic asthma.

' non-atopic wheeze.

${ }^{m}$ ratio of income to the family's appropriate poverty threshold (US Census Bureau).

virus (VZV), Epstein-Barr virus (EBV), Hepatitis A (HAV) and Ascaris lumbricoides and for levels of allergen specific IgE to Dermatophagoides pteronyssinus, Blomia tropicalis, Blattella germanica and Periplaneta americana (ImmunoCAP assay, Pharmacia, Uppsala, Sweden). Children were classified as atopic if the level of IgE to any of the 4 allergens was $>0.70 \mathrm{kU} / \mathrm{L}$. These four specific mite and cockroach allergens were chosen to measure atopy based on the findings of positivity to allergen skin prick tests to a panel of seven relevant aeroallergens. Positive skin prick tests to the four allergens accounted for $99 \%$ of all children with positive tests (389 out of 394). Based on atopy status and report of wheezing children were classified into 4 categories: 


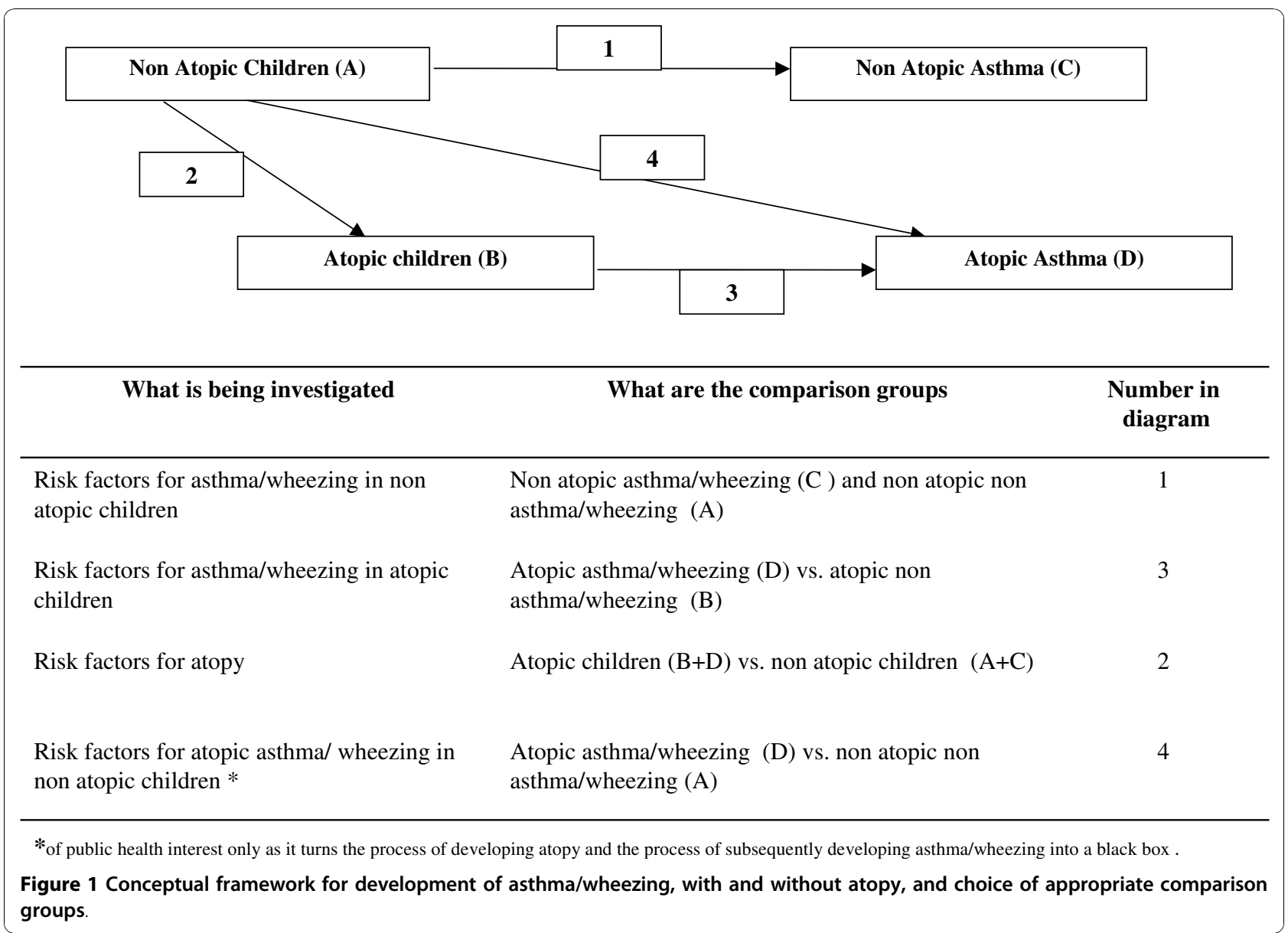

atopic wheezers, non-atopic wheezers, atopic nonwheezers, and non-atopic non-wheezers.

\section{Laboratory examinations}

HSV, VZV, EBV, T. gondii and H. pylori infections were diagnosed by detecting specific serum IgG using commercially available kits (Diamedix, Miami, FL, USA). Presence of anti-HAV IgG was determined using kits from ADALTIS (Toronto, Canada). This assays cut-offs were determined following the suppliers' directions, i.e., an index value obtained by the ratio Absorbance of sample/Absorbance of a calibrator (a solution containing human serum with moderate reactivity). A ratio value greater than 1.00 was considered positive. Anti-A. lumbricoides IgG4 was detected by indirect ELISA. Details of the technique were presented elsewhere [21].

\section{Statistical Analysis}

We investigated separately risk factors for asthma among non-atopic children, among atopic children, and for being atopic in the overall population, following the conceptual framework, and using the comparison groups described in Figure 1. We used bivariate and multivariate multinomial logistic regression [22] to identify separately risk factors for wheezing among nonatopic children (comparing non-atopic wheezers with non-atopic non-wheezers) and risk factors for wheezing among atopic children (comparing atopic wheezers with atopic non-wheezers). We used multinomial logistic regression because it treats the categories of the polytomy (atopic wheezers, non-atopic wheezers, atopic non-wheezers, and non-atopic non-wheezers) in a nonarbitrary order and also addresses several sets of log-odds, corresponding to different dichotomies. In addition to this, polychotomous logistic regression allows the construction of statistical significance tests of the variables accounting for simultaneous differences in probabilities of all the response categories, and not just individual groups. A separate analysis was done using ordinary logistic regression to study risk factors for atopy, comparing atopic children with non-atopic children, irrespective of wheeze. A backward elimination procedure using likelihood ratio test (p-value $<10 \%$ ) was adopted for all analyses to remove variables individually. Analyses for potential risk factors, apart from respiratory symptoms, were done with 1,309 children 
for whom complete data were available. Analyses were done using STATA, version 10 (StataCorp, College Station, TX, USA).

\section{Ethics}

Ethical approval was obtained from the Brazilian National Ethical Committee and from the LSHTM. Written informed consent was obtained from the legal guardians.

\section{Results}

Among the 1,309 children - 384 (29.3\%) reported wheezing in the last 12 months and 486 (37.1\%) had specific IgE in the serum above $0.70 \mathrm{kU} / \mathrm{L}$ for at least one of the tested allergens. Children were classified into 4 groups: non-atopic non-wheezers (613 children), atopic non-wheezers (312), non-atopic wheezers (210), and atopic wheezers (174). The prevalence of wheezing was $34.8 \%$ among atopic children, while this prevalence was $25.0 \%$ among non-atopic children. Atopic children were $60 \%$ more likely to wheeze than non-atopic children with OR $=1.60(1,26 ; 2.04)$.

Table 2 presents description of the demographic, social and environmental variables for each group classified based on atopy and wheezing. Some of these distributions does not seem to change across the groups, like child's sex and maternal education. However, a higher prevalence of parental asthma is verified among nonatopy wheezers and atopic wheezers $(21.4 \%$ and $17.4 \%$, respectively). Prolonged respiratory infection ( $\geq 8$ days) in early childhood is also observed in these groups (prevalences of $11.0 \%$ and $10.0 \%$, respectively). At the same time, a greater proportion of atopic (non-wheezers and wheezers) children had detectable values for IgG4 (19.4\% and 22.4\%) compared to non atopics (non-wheezers and wheezers) children ( $12.7 \%$ and $16.2 \%$, respectively). A table listing the results with all investigated variables is available in the Additional file 1, Table S1.

Table 3 presents adjusted associations between the demographic, social and environmental variables. This table presents results related to the adjustment of two models: the multinomial logistic regression (results in the second and third columns) and binary logistic regression for atopy (results in the fourth column). For the multinomial logistic regression, we only presented those results that discriminate risk factors for atopic and non-atopic/wheezing phenotypes. Variables are shown that were meaningfully associated with at least one outcome either in univariate or multivariate analysis. Crude associations obtained from univariate regression models are presented in Additional file 1, Table S1. The directions of the associations did not change considering crude and adjusted measures, and the changes of magnitude of these associations were generally modest. The lack of significance observed for some associations likely reflects lack of power. In general, parental asthma and frequent respiratory infections in childhood increased the risk of wheeze in both atopic and non-atopic children. Factors associated with wheeze only in non-atopic children were mainly related to dirt, infections or poverty: infrequent household cleaning, household rodent infestations, having attended day care and having had frequent respiratory infections and diarrhea in childhood and low maternal educational level. No factors were associated with wheeze only in atopic children. The only factor that was associated with a meaningful increase in atopy was the presence of IgG4 to A lumbricoides, a marker of past or active ascariasis.

\section{Discussion}

The present study showed many differences in risk factors for wheezing in atopic and non-atopic children. Common risk factors for the two wheeze phenotypes were parental asthma (with an effect of similar magnitude in atopic and non-atopic wheezers), and to a lesser degree respiratory infections in early childhood (with a weaker effect in atopic children). No other studied factor was meaningfully associated with wheezing in atopic children, but several factors were associated with wheezing in non-atopic children. These were related to poverty and dirt (lower maternal educational level, lower frequency of routine room cleaning, reported presence of rodents in or around the house) and having attended day care, a potential marker of greater contact between young children and greater infectious exposures during childhood. The only factors associated with atopy - measured as level of allergen specific IgE above $0.70 \mathrm{kU} / \mathrm{L}$ were seropositivity (IgG) to T. gondii (lowering the risk) and the presence of IgG4 to A. lumbricoides (increasing the risk).

There is an extensive literature on risk factors for asthma/wheezing, but very often studies do not discriminate between atopic and non-atopic asthma/wheezing phenotypes. The scarce literature that discriminates between risk factors for the two phenotypes is difficult to interpret because of differences in comparison groups used. This is a problem because the choice of comparison groups defines the study question. Briefly, as presented in Table 1, studies of risk factors for atopic asthma/wheezing have used three different comparison groups: (i) atopic with no asthma/wheezing [7,9,23], (ii) non-atopic with no asthma/wheezing $[6,12,13]$, and (iii) no-asthma/wheezing irrespective of atopy $[8,10,11]$. The first comparison group, which we used in our study, correctly identified risk factors for the development of asthma/wheezing in atopic children. The risk estimated when the second group is used includes both risks for development of atopy and for development of asthma/ 
Table 2 Distribution of potential risk factors according to atopy-wheezing groups in 1,309 children

\begin{tabular}{|c|c|c|c|c|c|c|}
\hline \multirow[b]{2}{*}{ Potential risk factors } & \multicolumn{3}{|c|}{ Non atopic } & \multicolumn{3}{|c|}{ Atopic } \\
\hline & $\begin{array}{c}\text { overall } \\
(\mathrm{N}=823)\end{array}$ & $\begin{array}{c}\text { non-wheezers } \\
(\mathrm{N}=613)\end{array}$ & $\begin{array}{l}\text { wheezers } \\
(\mathrm{N}=210)\end{array}$ & $\begin{array}{c}\text { overall } \\
(N=486)\end{array}$ & $\begin{array}{c}\text { non-wheezers } \\
(\mathrm{N}=312)\end{array}$ & $\begin{array}{l}\text { wheezers } \\
(N=174)\end{array}$ \\
\hline \multicolumn{7}{|l|}{ Social/familial and Demographic factors } \\
\hline \multicolumn{7}{|l|}{ Sex } \\
\hline Female & 46.1 & 46.2 & 45.7 & 49.0 & 51.3 & 44.8 \\
\hline Male & 53.9 & 53.8 & 54.3 & 51.0 & 48.7 & 55.2 \\
\hline \multicolumn{7}{|l|}{ Age } \\
\hline$<5$ & 36.1 & 31.0 & 51.0 & 33.7 & 28.8 & 42.5 \\
\hline $6-7$ & 35.5 & 37.0 & 31.0 & 35.8 & 37.2 & 33.3 \\
\hline$>8$ & 28.4 & 32.0 & 18.0 & 30.5 & 34.0 & 24.1 \\
\hline \multicolumn{7}{|l|}{ Mother education } \\
\hline Elementary education & 21.9 & 20.6 & 25.7 & 22.4 & 21.2 & 24.7 \\
\hline More than elementary education & 47.3 & 48.1 & 50.5 & 35.8 & 48.4 & 45.4 \\
\hline More than high school & 29.4 & 31.3 & 23.8 & 30.2 & 30.4 & 29.9 \\
\hline \multicolumn{7}{|l|}{ Parental Asthma } \\
\hline No & 85.4 & 87.8 & 78.6 & 88.9 & 92.3 & 82.8 \\
\hline Yes & 14.6 & 12.2 & 21.4 & 11.1 & 7.7 & 17.2 \\
\hline \multicolumn{7}{|l|}{ Dirt and Infections } \\
\hline \multicolumn{7}{|l|}{ Routine cleaning in all the rooms } \\
\hline No & 4.7 & 3.4 & 8.6 & 3.3 & 2.2 & 5.2 \\
\hline Yes & 95.3 & 96.6 & 91.4 & 96.7 & 97.8 & 94.8 \\
\hline \multicolumn{7}{|l|}{ Having attended day care } \\
\hline No & 83.6 & 85.8 & 77.1 & 84.6 & 84.3 & 85.1 \\
\hline Yes & 16.4 & 14.2 & 22.9 & 15.4 & 15.7 & 14.9 \\
\hline \multicolumn{7}{|l|}{ Rodents in the household } \\
\hline No & 41.4 & 44.5 & 32.4 & 44.7 & 43.3 & 47.1 \\
\hline Yes & 58.6 & 55.5 & 67.6 & 55.3 & 56.7 & 52.9 \\
\hline \multicolumn{7}{|l|}{ Tgondi } \\
\hline No & 80.1 & 80.6 & 78.6 & 84.8 & 86.2 & 82.2 \\
\hline Yes & 19.9 & 19.4 & 21.4 & 15.2 & 13.8 & 17.8 \\
\hline \multicolumn{7}{|l|}{$\lg G 4$} \\
\hline No detectable & 86.4 & 87.3 & 83.8 & 79.4 & 80.4 & 77.6 \\
\hline Detectable & 13.6 & 12.7 & 16.2 & 20.6 & 19.6 & 22.4 \\
\hline \multicolumn{7}{|l|}{ Respiratory symptoms } \\
\hline No & 68.3 & 72.1 & 56.7 & 69.2 & 73.2 & 60.8 \\
\hline For 1-7 days & 26.6 & 24.7 & 32.3 & 24.3 & 21.9 & 29.2 \\
\hline For $\geq 8$ days & 5.1 & 3.2 & 11.0 & 6.5 & 4.9 & 10.0 \\
\hline \multicolumn{7}{|l|}{ Diarrhoea } \\
\hline No & 24.8 & 26.1 & 20.7 & 23.0 & 23.5 & 22.1 \\
\hline For 1-7 days & 43.9 & 45.6 & 38.7 & 47.5 & 49.0 & 44.3 \\
\hline For $\geq 8$ days & 31.3 & 28.3 & 40.6 & 29.5 & 27.5 & 33.6 \\
\hline
\end{tabular}

wheezing in atopic children, although not helpful in understanding causation could have a public health purpose. The use of the third group generates results not really interpretable as the presence of atopic and nonatopic children in the comparison group generates an arbitrary combination of risks for development of asthma/wheezing in atopic children and risks for the development of atopy. Two different comparison groups have been used to study risk factors for non-atopic asthma/wheezing: non-atopic with no asthma/wheezing $[7,10,13,23]$ and children with no asthma irrespective of atopy $[8,9,11,12]$. The first comparison group, which we used in our study, correctly identified risk factors for the development of asthma/wheezing in non-atopic 
Table 3 Multivariate analysisa of potential risk factors related to development of atopic and non-atopic wheezing and atopy in 1,309 children

\begin{tabular}{|c|c|c|c|}
\hline \multirow[t]{2}{*}{ Potential risk factors } & $\begin{array}{l}\text { Non-atopic wheezers (vs. non-atopic } \\
\text { non-wheezers) }\end{array}$ & $\begin{array}{c}\text { Atopic wheezers (vs. atopic non- } \\
\text { wheezers) }^{\text {b }}\end{array}$ & $\begin{array}{l}\text { Atopic (vs. non- } \\
\text { atopics) }\end{array}$ \\
\hline & OR $(95 \% \mathrm{Cl})$ & OR $(95 \% \mathrm{Cl})$ & OR $(95 \% \mathrm{Cl})$ \\
\hline \multicolumn{4}{|l|}{ Social/familial factors } \\
\hline \multicolumn{4}{|l|}{ Mother education (reference group: High) } \\
\hline Medium & 1.30 (0.88 to 1.93$)$ & 0.94 (0.60 to 1.46$)$ & $0.95(0.73$ to 1.24$)$ \\
\hline Low(elementary or illiterate) & 1.49 (0.93 to 2.38$)$ & $1.24(0.73$ to 2.11$)$ & 1.01 (0.73 to 1.39$)$ \\
\hline $\begin{array}{l}\text { Parental Asthma (reference: no parental } \\
\text { asthma) }\end{array}$ & 1.91 (1.25 to 2.92$)$ & 2.64 (1.48 to 4.73$)$ & $0.73(0.51$ to 1.03$)$ \\
\hline \multicolumn{4}{|l|}{ Dirt and Infections } \\
\hline $\begin{array}{l}\text { Infrequent household cleaning (reference: } \\
\text { frequent cleaning) }\end{array}$ & 2.49 (1.27 to 4.90$)$ & 2.27 (0.82 to 6.29) & $0.72(0.39$ to 1.31$)$ \\
\hline Rodents in home (reference: no rodents) & 1.68 (1.21 to 2.34$)$ & 0.79 (0.54 to 1.15$)$ & $0.90(0.71$ to 1.13$)$ \\
\hline $\begin{array}{l}\text { Having attended day care (reference: no } \\
\text { attendance) }\end{array}$ & $1.52(1.01$ to 2.29$)$ & $0.83(0.49$ to 1.41$)$ & $0.92(0.67$ to 1.26$)$ \\
\hline T. gondii seropositivity (reference: negative) & $1.23(0.82$ to 1.84$)$ & 1.51 (0.90 to 2.54$)$ & 0.68 (0.50 to 0.93$)$ \\
\hline $\begin{array}{l}\text { A. lumbricoides-specific lgG4 (reference: } \\
\text { negative) }\end{array}$ & 1.25 (0.79 to 1.97$)$ & $1.20(0.75$ to 1.92$)$ & $1.73(1.27$ to 2.34$)$ \\
\hline \multicolumn{4}{|l|}{$\begin{array}{l}\text { Respiratory symptoms (reference: no } \\
\text { symptoms) }\end{array}$} \\
\hline for 1-7 days & 1.54 (1.01 to 2.36$)$ & 1.54 (0.92 to 2.59$)$ & $0.89(0.65$ to 1.21$)$ \\
\hline for $\geq 8$ days & 4.87 (2.26 to 9.76$)$ & 2.27 (0.97 to 5.38$)$ & 1.31 (0.74 to 2.31$)$ \\
\hline \multicolumn{4}{|l|}{ Diarrhea (reference: no diarrhoea) } \\
\hline for 1-7 days & 1.09 (0.67 to 1.80$)$ & $1.02(0.58$ to 1.81$)$ & 1.18 (0.85 to 1.64$)$ \\
\hline for $\geq 8$ days & 1.59 (0.95 to 2.66$)$ & 1.29 (0.70 to 2.40$)$ & $1.03(0.72$ to 1.49$)$ \\
\hline
\end{tabular}

a controlled by age and sex, and adjusted for all factors included in the table.

${ }^{b}$ multinomial logistic regression.

c ordinary logistic regression.

children. The second group generate results that are difficult to interpret because they merge risks for the development of asthma/wheezing in non-atopic children and protection against the development of atopy.

Taking these issues into account, epidemiological studies reported to date have identified respiratory infections in early childhood $[10,13,24]$, family history of asthma $[6-9,11,13]$ and smoking in the household $[7-9,12]$ to be more consistently associated with non-atopic asthma. Several of these studies have reported factors that while not reproduced consistently, can be interpreted as being related to different aspects of poverty, infection and dirt (parental education, dampness, mould stains, dirt school, pets, and endotoxin exposure) $[7,8,11,12,23]$.

While there is evidence that atopy may increase with socioeconomic status $[25,26]$, the relationship between socioeconomic status and asthma/wheezing is more complex [27]. Within Europe, asthma/wheezing used to be more common among individuals of high socioeconomic status and that this trend may have reversed in recent years $[28,29]$. In the USA, asthma/wheezing is clearly more frequent in poor inner city populations although there is no evidence to clarify whether this is attributable to a greater prevalence or poor asthma control because of more limited access to health care [30,31]. Studies in urban environments in Latin America have reported a very high prevalence of wheezing among children living in poor neighborhoods [32]. A recent ecological analysis of survey data using population samples from 64 countries has described a bimodal asthma distribution with a higher prevalence in low-income and high-income countries, and lower prevalence in middle-income countries [33]. Conflicting results may have resulted from a failure to discriminate atopic from non-atopic asthma/wheezing. There are indications that markers of dirt may have opposite effects in the atopic and non-atopic phenotypes [34]. It is essential that further studies investigate separately atopic and non-atopic asthma/wheezing.

There are plausible mechanisms by which poverty may increase the prevalence of non-atopic asthma/wheezing. In one study, reduced exposure to second-hand cigarette smoke explained a significant proportion of the protection against non-atopic wheezing in highly educated families [12]. Respiratory infections [35] and dirt [36] are also more frequent among the poorest. There is an interesting ongoing discussion about a role for exposure 
to endotoxin, a highly immunologically active constituent of cell walls of gram-negative bacteria - as the mechanism by which 'dirt' may induce the inflammatory effects in the lungs that could underlie non-atopic asthma. This has been proposed as a potential mechanism for the lower prevalence of asthma/wheezing and allergic rhinitis in rural areas of Europe [30]. There is evidence that high-level exposures to endotoxin can have a protective effect on atopic asthma/wheezing but may increase the risk of non-atopic asthma/wheezing [23,34,37]. Thus, microbial exposures may somewhat paradoxically be a protective factor for atopic asthma/ wheezing but an important risk factor for non-atopic asthma/wheezing. Attending day care is associated with an increased risk of respiratory infections [38].

The present study may have lacked power to detect some associations because of loss of power by separation of children in atopic and non-atopic wheezers. However, this separation is one of the strengths of the study. Other strengths are: (i) allergen specific IgE was measured for all children and not restricted to wheezers; (ii) risk factors for atopic and non-atopic wheeze were studied in the same population, and multinomial logistic regression analysis was used to maximize the value of using the same population; (iii) analysis was informed by a conceptual framework, and therefore used the appropriate comparison group to study risk factors for wheezing in atopic and non-atopic children; (iv) early and late potential risk factors were measured concurrently, avoiding recall bias; and (v) is the first study to assess separately risk factors for atopic and non-atopic wheezing in an urban context in a developing country.

In conclusion, parental asthma and early life respiratory infections increased the risk of wheezing in atopic and non-atopic children, but other factors were associated only with non-atopic wheezing. These factors were associated with poverty, dirt and infections: low maternal educational level, infrequent cleaning of the house, household rodent infestation, and having attended day care. There is a need for further research into risk factors for asthma that investigate separately atopic and non-atopic individuals using appropriate comparison groups as indicated in the proposed framework. Such studies should explore further the relationship between socioeconomic status and non-atopic wheezing to clarify which aspects of poverty and dirt mediate the associations observed.

\section{Additional material}

Additional file 1: Table S1. Univariate association of socioeconomic, demographic, environmental and personal factors with wheezing with and without atopy in 1,309 children.

\section{Authors' contributions}

MLB and LCR participated in the study design in the interpretation of data and drafted the manuscript; SSC, AAC, PJC, DNS, NA-N, RF, RE and LDA contributed to the analysis, interpretation and drafting of the manuscript; SA, MP, AS contributed to the data collection, analysis, interpretation and drafting of the manuscript. All authors read and approved the final manuscript.

\section{Conflict of interests}

The authors declare that they have no competing interests.

\section{Acknowledgements}

This study is part of the SCAALA Programme (Social Change, Asthma and Allergy in Latin America), which is funded by The Welcome Trust, UK, Ref 072405/Z/03/Z. Complementary funds were received from the INCT/CNPq Programme Ref 610011/2009-0. We are very grateful to children and parents, without whose generous participation this study would not have been possible

\section{Author details}

${ }^{1}$ Instituto de Saúde Coletiva, Universidade Federal da Bahia, Salvador, Brazil. 2 Departamento Medicina Social, Universidade Federal de Pernambuco, Recife, Brazil. ${ }^{3}$ Departamento de Estatística, Universidade Federal da Bahia, Salvador, Brazil. ${ }^{4}$ ProAR, Faculdade de Medicina, Universidade Federal da Bahia, Salvador, Brazil. ${ }^{5}$ Colegio de Ciências de la Salud, Universidad San Francisco de Quito, Quito, Ecuador. ${ }^{6}$ Instituto de Ciências da Saúde, Universidade Federal da Bahia, Salvador, Brazil. ${ }^{7}$ London School of Hygiene and Tropical Medicine, London, UK.

Received: 9 August 2010 Accepted: 1 December 2010 Published: 1 December 2010

\section{References}

1. Masoli M, Fabian D, Holt S, Beasley R, Global Initiative for Asthma (GINA) Program: The global burden of asthma: executive summary of the GINA Dissemination Committee report. Allergy 2004, 59:469-478.

2. Asher Ml, Montefort S, Björkstén B, Lai CK, Strachan DP, Weiland SK, Williams H, ISAAC Phase Three Study Group: Worldwide time trends in the prevalence of symptoms of asthma. allergic rhinoconjunctivitis. and eczema in childhood: ISAAC Phases One and Three repeat multicountry cross-sectional surveys. Lancet 2006, 368:733-743.

3. Weinmayr $G$, Weiland SK, Björkstén B, Brunekreef B, Büchele $G$, Cookson WO, Garcia-Marcos L, Gotua M, Gratziou C, van Hage M, von Mutius E, Riikjärv MA, Rzehak P, Stein RT, Strachan DP, Tsanakas J, Wickens K, Wong GW, ISAAC Phase Two Study Group: Atopic sensitization and the international variation of asthma symptom prevalence in children. Am J Respir Crit Care Med 2007, 176:565-574.

4. [No authors listed]. Worldwide variation in prevalence of symptoms of asthma. allergic rhinoconjunctivitis. and atopic eczema: ISAAC: The International Study of Asthma and Allergies in Childhood (ISAAC) Steering Committee. Lancet 1998, 351:1225-1232.

5. Cooper PJ, Rodrigues LC, Cruz AA, Barreto ML: Asthma in Latin America: a public heath challenge and research opportunity. Allergy 2009, 64:5-17.

6. Moncayo AL, Vaca M, Oviedo G, Erazo S, Quinzo I, Fiaccone RL, Chico ME, Barreto ML, Cooper PJ: Risk factors of atopic and non-atopic asthma in a rural area of Ecuador. Thorax 2010, 65:409-416.

7. Rönmark E, Jönsson E, Platts-Mills T, Lundbäck B: Different pattern of risk factors for atopic and nonatopic asthma among children - Report from the Obstructive Lung Disease in Northern Sweden Study. Allergy 1999, 54:926-35.

8. Priftanji AV, Qirko E, Burr ML, Layzell JC, Williams KL: Factors associated with asthma in Albania. Allergy 2002, 57:123-128.

9. García-Marcos L, Castro-Rodríguez JA, Suarez-Varela MM, Garrido JB, Hernandez GG, Gimeno AM, González AL, Ruiz TR, Torres AM: A different pattern of risk factors for atopic and non-atopic wheezing in 9-12-yearold children. Pediatr Allergy Immunol 2005, 16:471-477.

10. Kelley CF, Mannino DM, Homa DM, Savage-Brown A, Holguin F: Asthma phenotypes. risk factors. and measures of severity in a national sample of US children. Pediatrics 2005, 115:726-731. 
11. Janson C, Kalm-Stephens P, Foucard T, Alving K, Nordvall SL: Risk factors associated with allergic and non-allergic asthma in adolescents. Clin Respir J 2007, 1:16-22.

12. de Meer G, Reijneveld SA, Brunekreef B: Wheeze in children: the impact of parental education on atopic and non-atopic symptoms. Pediatr Allergy Immunol 2009, 21:823-30.

13. Kurukulaaratchy RJ, Fenn M, Matthews S, Arshad SH: Characterisation of atopic and non-atopic wheeze in 10 year old children. Thorax 2004, 59:563-568.

14. Solé D, Camelo-Nunes IC, Wandalsen GF, Mallozi MC, Naspitz CK, Brazilian ISAAC's Group: Is the prevalence of asthma and related symptoms among Brazilian children related to socioeconomic status? J Asthma 2008, 45:19-25.

15. Barreto ML, Cunha SS, Alcântara-Neves N, Carvalho LP, Cruz AA, Stein RT, Genser B, Cooper PJ, Rodrigues LC: Risk factors and immunological pathways for asthma and other allergic diseases in children: background and methodology of a longitudinal study in a large urban center in Northeastern Brazil (Salvador-SCAALA Study). BMC Pulm Med 2006, 6:15.

16. Barreto ML, Genser B, Strina A, Teixeira MG, Assis AM, Rego RF, Teles CA, Prado MS, Matos SM, Santos DN, dos Santos LA, Cairncross S: Effect of citywide sanitation programme on reduction in rate of childhood diarrhoea in northeast Brazil: assessment by two cohort studies. Lancet 2007, 370:1622-1628.

17. Mascarini-Serra LM, Telles CA, Prado MS, Mattos SA, Strina A, AlcantaraNeves NM, Barreto ML: Reductions in the Prevalence and Incidence of Geohelminth Infections following a City-wide Sanitation Program in a Brazilian Urban Centre. PLoS Negl Trop Dis 2010, 4(2):e588.

18. Barreto ML, Genser B, Strina A, Teixeira MG, Assis AMO, Rego RF, Teles CA, Prado MS, Matos SMA, Alcântara-Neves NM, Cairncross S: Impact of a CityWide Sanitation Programme in Northeast Brazil on Intestinal Parasites Infection in Young Children. Environ Health Perspect 2010,

118(11):1637-1642.

19. Teixeira MG, Barreto ML, Costa MCN, Strina A, Martins Júnior D, Prado M: Sentinel areas: na strategy for public health montoring. Cad Saúde Pública 2002, 18:1189-1195.

20. Solé D, Vanna AT, Yamada E, Rizzo MC, Naspitz CK: International Study of Asthma and Allergies in Childhood (ISAAC) written questionnaire: validation of the asthma component among Brazilian children. J Investig Allergol Clin Immunol 1998, 8:376-338.

21. Figueiredo CA, Barreto ML, Rodrigues LC, Cooper PJ, Silva NB, Amorim LD, Alcantara-Neves NM: Chronic intestinal helminth infections are associated with immune hyporesponsiveness and induction of a regulatory network. Infection and Immunity 2010, 78(7):3160-7.

22. Hosmer DW, Lemeshow S: Applied logistic regression. 2 edition. New York: John Wiley \& Sons Inc; 2000.

23. Braun-Fahrländer C, Riedler J, Herz U, Eder W, Waser M, Grize L, Maisch S, Carr D, Gerlach F, Bufe A, Lauener RP, Schierl R, Renz H, Nowak D, von Mutius E, Allergy and Endotoxin Study Team: Environmental exposure to endotoxin and its relation to asthma in school-age children. $N$ Engl J Med 2002, 347:869-877.

24. Pereira MU, Sly PD, Pitrez PM, Jones MH, Escouto D, Dias AC, Weiland SK, Stein RT: Nonatopic asthma is associated with helminth infections and bronchiolitis in poor children. Eur Respir J 2007, 29:1154-1160.

25. Addo-Yobo EO, Woodcock A, Allotey A, Baffoe-Bonnie B, Strachan D, Custovic A: Exercise-induced bronchospasm and atopy in Ghana: two surveys ten years apart. PLoS Med 2007, 4:e70.

26. Perzanowski MS, Ng'ang'a LW, Carter MC, Odhiambo J, Ngari P, Vaughan JW, Chapman MD, Kennedy MW, Platts-Mills TA: Atopy, asthma. and antibodies to Ascaris among rural and urban children in Kenya. J Pediatr 2002, 40:582-588.

27. Cunha SS, Barreto ML, Rodrigues LC: The importance of research on the association between socioeconomic conditions and asthma. Rev Panam Salud Publica 2007, 22:438-440.

28. Braback L, Hjern A, Rasmussen F: Social class in asthma and allergic rhinitis: a national cohort over three decades. Eur Respir J 2005, 26:1-5.

29. Bergmann RL, Edenharter G, Bergmann KE, Lau S, Wahn U: Socioeconomic status is a risk factor for allergy in parents but not in their children. Clin Exp Allergy 2000, 30:1740-1745.

30. Kozyrskyj AL, Kendall GE, Jacoby P, Sly PD, Zubrick SR: Association between socioeconomic status and the development of asthma: analyses of income trajectories. Am J Publ Health 2010, 100:540-546.
31. Gold DR, Wright R: Population disparities in asthma. Annu Rev Public Health 2005, 26:89-113.

32. Mallol J, Castro-Rodriguez JA, Cortez E, Aguirre V, Aguilar P, Barrueto L: Heightened bronchial hyperresponsiveness in the absence of heightened atopy in children with current wheezing and low income status. Thorax 2008, 3:167-171.

33. Sembajwe G, Cifuentes M, Tak SW, Kriebel D, Gore R, Punnett L: National income. self-reported wheezing and asthma diagnosis from the World Health Survey. Eur Respir J 2010, 35:279-286.

34. Eder W, Ege MJ, von Mutius E: The asthma epidemic. N Engl J Med 2006, 23(355):2226-2235

35. Frietsch SO, Fischer GB, César JA, Lempek BS, Barbosa LV Jr, Zogbi L, Cardoso OC, Santos AM: Acute lower respiratory illness in under-five children in Rio Grande, Rio Grande do Sul State, Brazil: prevalence and risk factors. Cad Saude Publica 2008, 24:1429-1438.

36. Gorter AC, Sandiford P, Pauw J, Morales P, Pérez RM, Alberts H: Hygiene behaviour in rural Nicaragua in relation to diarrhoea. Int J Epidemiol 1998, 27:1090-100.

37. Eduard W, Douwes J, Omenaas E, Heederik D: Do farming exposures cause or prevent asthma? Results from a study of adult Norwegian farmers. Thorax 2004, 59:381-386.

38. Kamper-Jørgensen M, Wohlfahrt J, Simonsen J, Grønbaek M, Benn CS: Population-based study of the impact of childcare attendance on hospitalizations for acute respiratory infections. Pediatrics 2006, 118:1439-1446.

doi:10.1186/1465-9921-11-167

Cite this article as: Barreto et al:: Poverty, dirt, infections and non-atopic wheezing in children from a Brazilian urban center. Respiratory Research 2010 11:167.

\section{Submit your next manuscript to BioMed Central and take full advantage of:}

- Convenient online submission

- Thorough peer review

- No space constraints or color figure charges

- Immediate publication on acceptance

- Inclusion in PubMed, CAS, Scopus and Google Scholar

- Research which is freely available for redistribution

Submit your manuscript at www.biomedcentral.com/submit
Biomed Central 